\title{
Attributes And Consequences Of Customer Satisfaction In Tourism Industry: The Case Of Polish Travel Agencies
}

Andrzej Kobylanski, Ph.D., Penn State Greater Allegheny, USA

\begin{abstract}
The term "customer satisfaction" still has an abstract meaning for managers in developing countries. This study focuses on travel agencies in Poland, to improve managers' awareness of how customer satisfaction can directly improve business performance. Authors investigated nine attributes of the travel agency service, and identified four of them that have significant effect on overall customer satisfaction ("quality of the offer," "safety," "convenience" and "comparison of the delivered service with the advertising message"). Furthermore, this paper demonstrates that a high level of customer satisfaction in travel agencies creates certain effects like positive word-ofmouth and customer loyalty, which impacts long-term business performance.
\end{abstract}

Keywords: Customer Satisfaction; Travel Agencies; Poland; Tourism

\section{LITERATURE REVIEW}

$\mathrm{n}$ an environment where many organizations provide similar product offerings at close price range and media channels face constant clutter, it seems that delivering a high level of customer satisfaction could be an important component of a company's distinctiveness over competitors. This paradigm of customer satisfaction has been known for many years in the developed countries. However, it is still a relatively new concept in Poland. Only some industries slowly discover and acknowledge that managing customer satisfaction is an important part of the processes of quality management and customer relationship management.

There are a number of discussions in marketing literature devoted to the effects of customer satisfaction on business performance. Many managers and decision makers understand the importance of customer satisfaction on business performance, however they find this very difficult to implement in practice. Their main skepticism is based on the assumption that results obtained from the customer satisfaction measurement don't have a place in the financial reports. Therefore, customer satisfaction management is still seen as a cost of conducting marketing research rather than investment in building long term relationships. We summarize some of the literature findings in Table 1.

One of the first attempts to respond to this criticism was research done by Fornell (1996), which resulted in designing the American Customer Satisfaction Index (ACSI), proving a correlation between customer satisfaction and economic results of business organizations in different economic sectors. Lawson and Glowa (2001) stress that customer satisfaction is the key component in building the brand equity, which, in the long run, it will translate into customer loyalty. Close monitoring of changes in the level of consumer satisfaction along with other sources of information could be helpful as a diagnostic tool to identify potential problem areas before they will cause serious complications (Pasquier and Fastnacht, 2001). Therefore, customer satisfaction measurement should be viewed not only as an indicator of service quality, but also as a factor that makes an impact on improving business performance. Research conducted by Radhakrishna (2002) provides evidence of the impact of customer satisfaction on business performance in the consulting services sector. Warnock (1992) made similar observations and showed that information about customer satisfaction from the US government agencies indeed improved quality and effectiveness of services provided by these agencies. 
Table 1. Effects of Customer Satisfaction in the Literature

\begin{tabular}{|c|c|c|}
\hline CATEGORY & RELATED CONCEPT & REFERENCE \\
\hline \multirow{17}{*}{$\begin{array}{l}\text { Financial effects } \\
\text { (Quantitative effects) }\end{array}$} & \multirow[t]{5}{*}{ Improvement of business performance } & Warnock (1992) \\
\hline & & Fornell $(1995,1996)$ \\
\hline & & Radhakrishna (2002) \\
\hline & & Anderson, Fornell and Mazvancheryl (2004) \\
\hline & & Fornell at al. (2006) \\
\hline & \multirow[t]{2}{*}{ Sale and profit growth } & Hartig (1997) \\
\hline & & Bolton, Kannan, and Bramlett (2000) \\
\hline & \multirow[t]{3}{*}{ Customer loyalty } & Fornell (1992) \\
\hline & & Bolton (1998) \\
\hline & & Morgan at al. (2000) \\
\hline & \multirow[t]{2}{*}{ Increase of organizational effectiveness } & Fornell at al. (2006) \\
\hline & & $\mathrm{Yu}(2007)$ \\
\hline & \multirow[t]{5}{*}{ Secure future revenue } & Rust and Zahorik (1993) \\
\hline & & Rust and Keiningham (1994) \\
\hline & & Zairii (2000) \\
\hline & & Rust, Moorman, and Dickson (2002) \\
\hline & & Anderson, Fornell and Mazvancheryl (2004) \\
\hline \multirow{21}{*}{$\begin{array}{l}\text { Non-financial effects } \\
\text { (Qualitative effects) }\end{array}$} & Measurement of service quality & Parasuraman at al. (1985) \\
\hline & \multirow{5}{*}{$\begin{array}{l}\text { Improved company reputation and positive } \\
\text { recommendations }\end{array}$} & Fornell (1992) \\
\hline & & Andreson and Sullivan (1993) \\
\hline & & Zairi (2000) \\
\hline & & Anderson, Fornell and Mazvancheryl (2004) \\
\hline & & Wangnheim and Bayon (2004) \\
\hline & \multirow{2}{*}{ Improvement of brand equity } & Andreson and Sullivan (1993) \\
\hline & & Lawson and Glowa (2000) \\
\hline & Measurement of Quality management systems & ISO $9001-2000$ \\
\hline & Identification of improvement areas & Pasquier (2001) \\
\hline & \multirow[t]{3}{*}{ Reduction of complaint behavior } & Fornell (1992) \\
\hline & & Bolton (1998) \\
\hline & & Barlow and Moller (2001) \\
\hline & \multirow[t]{3}{*}{ Decreased sensitivity to competitors' offer } & Anderson and Sullivan (1993) \\
\hline & & Gounaris and Stathakopoulos (2001) \\
\hline & & Mithas and Mitchell (2004) \\
\hline & \multirow{2}{*}{ Employee motivation } & Fastnacht (2001) \\
\hline & & Naumann and Hoisington (2001) \\
\hline & Effective promotion & Tan and Pawitra (2001) \\
\hline & \multirow[t]{2}{*}{ Positive message for customers } & Robertson and Gatignon (1986) \\
\hline & & Schneider (2000) \\
\hline
\end{tabular}

Zairii (2000) as well as Anderson et al. (2004) investigated long term effects of customer satisfaction and concluded that satisfied consumers make recommendations to others and therefore secure future revenues. Higher levels of customer satisfaction can also enhance a company's reputation (Fornell 1992, Andreson and Sullivan 1993, Wangnheim and Bayon 2004) and brand image (Lawson and Glowa 2000), which could lead to the creation of instant awareness and ease of acceptance of a new product, consequently reducing the costs of attracting new customers (Robertson and Gatignon, 1986). If managers are able to identify the magnitude of the relationship, they might be able to influence consumer behavior and therefore influence business performance through direct impact on future sales and business profitability. Possible consumer reactions determined by the level of customer satisfaction are presented in Figure 1.

Gounaris and Stathakopoulos (2001) indicated that consumers with high levels of satisfaction from goods or services: (1) make conscious decisions of long term commitment with the product or service provider; and (2) have a reduction of negative feelings that could lead to a change of service provider. High customer satisfaction has a negative impact on customer complaints (Bolton, 1998; Fornell, 1992; Barlow, Moller, 2001); thus, it can reduce costs associated with handling problems with poor quality services, defective products and warranties (Fornell, 1992). Anderson (1996) suggests that higher customer satisfaction can decrease price elasticity and reduce the 
possibility of consumer switching behavior (Anderson and Sullivan 1993; Mithas, Mitchell 2004). Recent studies suggest that customer satisfaction has a strong relationship with shareholder return (Anderson at al. 2004), and stock prices (Fornell, 2006), which could be important from the investor's point of view. Another area studied has been the effects of customer satisfaction relating to employees' motivation (Fastnacht, 2001). The same complex linkage was investigated by Naumann and Hoisington (2001). They discovered a positive relationship between customer satisfaction and employee satisfaction, market share and productivity indicators.
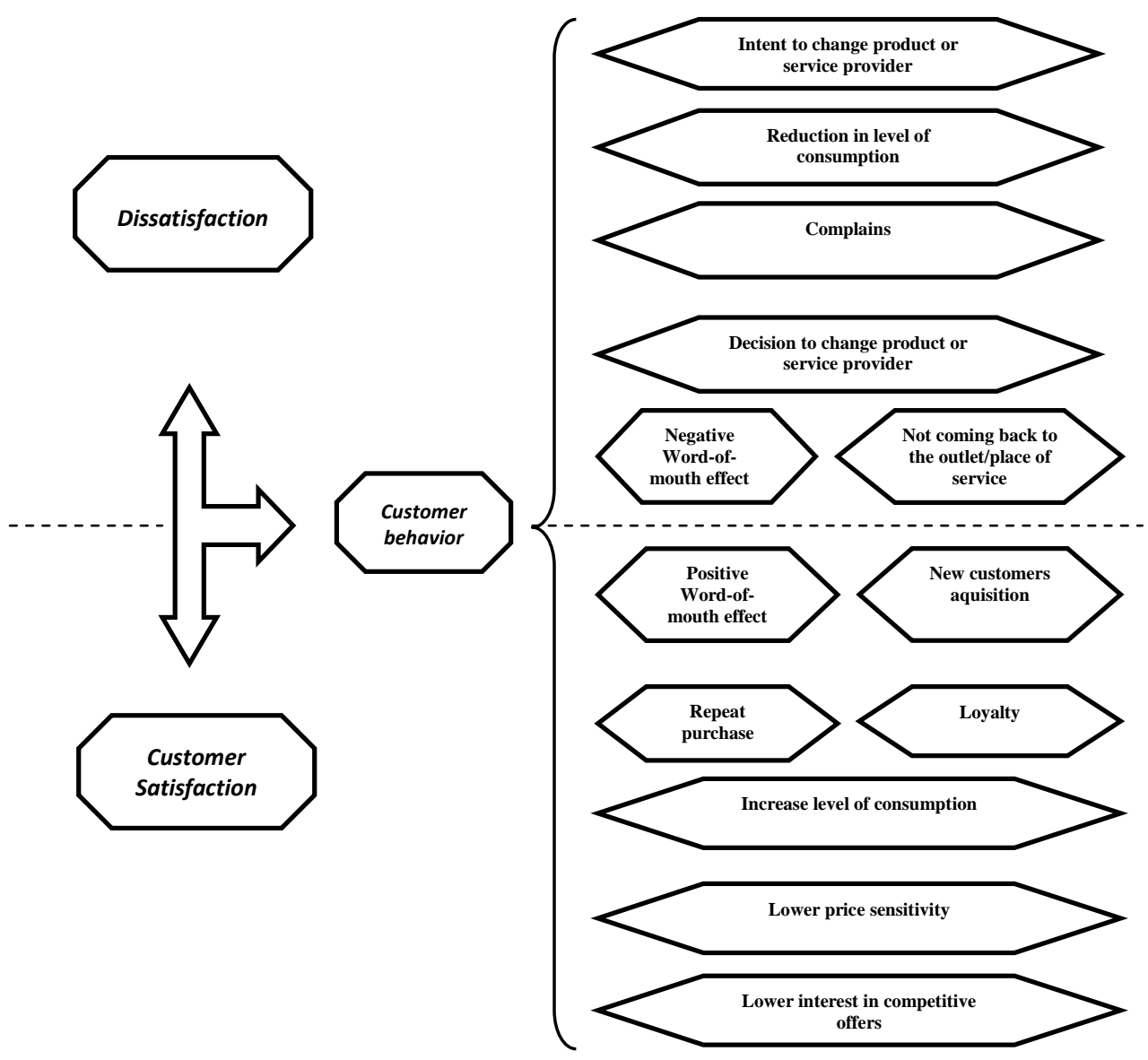

Figure 1. Customer reactions to satisfaction/dissatisfaction

\section{Tourist Satisfaction with Travel Agencies}

There are a number of approaches to define what customer satisfaction is. Zeithaml and Bitner (2000) describe it as "the customer's evaluation of product or service in terms of whether that product or service has met their needs and expectations." This definition is rooted in Oliver's (1980) disconfirmation paradigm, which states that satisfaction is believed to occur through the process of matching the expectations with perceived performance. Schneider (2000) defines satisfaction through its creation process. He suggests that it is the result of the psychological process in which the customer is making a comparison of the perceived level of organization performance to his/her specific standards, known as expectations. For the purpose of this study we use the definition by Woodruff and Gardial (1996): positive or negative emotional feedback associated with product or service value offered in a specific situation. According to this definition, customer satisfaction is the reaction to a specific product offering or the accumulation of overall experiences associated with a product or company. Considering the travel industry, where the product offering addresses hedonistic needs, we took into consideration 
the definition provided by Oliver $(1997,1999)$ : "satisfaction is defined as pleasurable fulfillment." Therefore, the overall experience of the tourist is evaluated based on fulfillment of his/her needs, wants, desires and aspirations. Consequently, "satisfaction is the tourist's sense that consumption provides outcomes against a standard of pleasure versus displeasure" (Moliner at al., 2006). Consequently, when determining satisfaction with a travel agency it is fundamental to identify the variables or affective reactions that customers take into account.

\section{DESIGN OF THE EMPIRICAL INVESTIGATION}

The objective of the study was to gain an understanding of the manager's knowledge and understanding of the effect of customer satisfaction on business performance, as well as identification of the variables that affect satisfaction with a travel agency. We also investigated the potential non-financial effects of customer satisfaction that in long-term perspective could positively influence business performance. This study has been conducted in the travel agencies sector where the business profitability is highly dependent on the level of customer satisfaction.

The following hypotheses have been formed:

H1: Low level of knowledge among managers and understanding of the effect of customer satisfaction is the main obstacle in collecting data and utilizing results in the decision-making process.

H2: Proper identification of core attributes that affect customer satisfaction provides leverage to effectively manage customer satisfaction.

H3: The higher the level of customer satisfaction the greater non-financial results of travel agencies.

\section{Study Methods}

The study consisted of a series of in-depth interviews with managers in travel agencies in one geographic region of Poland, as well as two surveys directed toward employees and customers of the investigated travel agencies. The in-depth interview has been structured with the standardized questionnaire containing 24 questions addressing company activities and actions associated with the measurement of customer satisfaction. Some questions investigated the level of entrepreneurial activity and identification of methods used to track customer satisfaction. In order to fully diagnose investigated topics we surveyed employees and customers of these firms using two standardized questionnaires. One was directed to customers to collect information about the level of satisfaction with purchased services, customers' perception of attributes that form overall satisfaction and intended actions as a consequence of their satisfaction. The second questionnaire has been directed toward travel agents and employees of travel agencies to obtain information about the knowledge of the concept of customer satisfaction and employee's assessment of factors affecting its level.

Because of the specifics of this industry and high failure rate in this sector we established one criterion for inclusion in this study pertaining to the age of the firm, and only firms that have been established for five years or more have been considered. Within these criteria 31 businesses have been identified; 20 businesses initially accepted participation in the study but five of them resigned during the time of the study. Collected data came from 15 firms and have been analyzed. However, data from seven organizations are incomplete; therefore for the final discussion we included eight travel agencies. The results have been discussed in the form of case studies based on information from these companies, which we denoted in this study using the following symbols: I, II, III, IV, V, VI, VII, VIII.

We conducted 15 in-depth interviews with managers and collected 48 useful surveys from employed personnel. From the 1500 surveys distributed to the customers of analyzed travel agencies, we collected 527, which gave a $35.13 \%$ response rate. In the obtained sample of customers, the gender distribution was as follows: $62 \%$ were women and $38 \%$ were men. The majority of clients of travel agencies are young people - almost half the respondents (45.7\%) were aged from 26 to 35 years. The second largest group was people from 36 to 45 years old - $28.5 \%$ of respondents. The distribution by age in the other groups was as follows: up to 25 years $-17.6 \%$, from 46 to 55 years - 7.4\% and above 55 years only $0.8 \%$. A characteristic feature of this population was a relatively high level of education - as much as $53.1 \%$ of respondents had a college degree, associate degree - $14 \%$, high school degree $31.5 \%$, and not having a degree $-1.8 \%$. 
Among 48 employees that completed the survey, $60.4 \%$ were women and $39.6 \%$ were men. The dominant group consisted of people between 26 and 35 years old - 45.8\%. Other age groups were: $27.1 \%$ for those $36-45$ years old, and $25 \%$ for people 46 to 55 years old. People employed in agencies and tourist offices are mainly highly educated $-56.3 \%$ college degree, and studying for or possessing an associate degree $-43.7 \%$. In the sector of tourism a very important factor is work experience. Employees with years of experience consisted of $56.1 \%$ of respondents (33.4\% over 6 years in the industry and $22.9 \%$ above 10 years). People with short work experience (less than 2 years) comprised $10.4 \%$ of respondents, while one third (33.3\%) of workers had experience of 2-5 years.

\section{DATA ANALYSIS}

\section{Attributes Affecting Customer Satisfaction}

In the case of satisfaction with a travel agency, the tourist evaluates a full range of goods or services offered by the travel agency and its evolution over time (Moliner, at al. 2007). In many publications it is stressed that the focus of the analysis should be on identification of satisfaction level on each of the key attributes of service. In some situations, as given in Shen, at al. (2000), customer satisfaction has been substantially increased even by only a small improvement in quality, but in those attributes that are critical for customers. For other attributes that are not important to them, the changes (even significant) may not produce any effect in improving the level of satisfaction. It is therefore important to identify the attributes that are most relevant to creation of satisfaction among customers. Therefore the customer satisfaction with a travel agency is a result of the relationship between the travel agency and tourists in the form of a construct made up of key components that reflect the overall service (HenningThurau et al., 2002). We made an attempt to determine the attributes and their importance, from the perspective of the customer, as well as travel agents. Comparison of the results allowed us to capture the differences between both groups that could have considerable influence on the level of customer satisfaction.

The in-depth analysis of customers' expectations made it possible to extract the determinants of customer satisfaction. As a first step we evaluated customers' responses in the survey according to the identified elements: the quality of tourist offer (an attractive destination place), price, reputation of organization, quality of service in the office, quality of service during the trip, convenience, safety, reliability, comparison of the delivered service with the advertising message. This analysis was based on a set of factors that have been ranked in priority order using the 1 to 10 scale, from the most important (10 pts.) to the least important factor (1pt.).

Customers agreed that three elements are most important to them: the quality of the offer, described as an attractive destination place (mean: 8.258), safety (mean: 6.567) and price (mean: 6.155) (Table 2). This hierarchy of attributes could be explained by the fact that customers are making decision to use the services of travel agents in situations where they do not want to or cannot organize vacation/travel by themselves. Therefore attractive place or travel package (product offering) is the most important factor that influences the overall satisfaction not only from the services of a travel agency, but also satisfaction from the vacation time. The importance of safety as a factor has increased considerably in recent years due to the uncertain geopolitical situation in the world and terrorism threats. These trends are seen in the global tourism market and travel agencies have a major challenge to assure customers of their safety during the trip. We also observed above average attention to the financial consequences of a purchasing decision as a factor affecting customer satisfaction. Because travel services are not necessities and customers have time constraints associated with vacation time, they tend to shop for value and they are willing to spend the money, provided they can justify the price by the quality of the offer.

The least important attribute indicated by clients of travel agencies was "Comparison of the delivered service with the advertising message" (mean: 4.711). It could suggest that travel agencies are doing a good job creating realistic expectations and the promised service (in most cases) has the same quality level as expected by customers. The impact of factors such as: service quality in the office (4.814) and service quality during the trip (5.732), have been estimated at an average level with the confirmation that quality of the delivered service during vacation (or travel) have much greater impact on the satisfaction level than quality of service in the office. This may also mean that customers are sometimes willing to accept the shortcomings associated with poor customer service, provided that the traveler will get an attractive product at a reasonable price, ensuring a safe vacation time. 
Table 2. Customers' and Employees' Perception of Attributes Affecting Customer Satisfaction

\begin{tabular}{|c|c|c|c|c|c|c|}
\hline Attribute & $\begin{array}{l}\text { Customers } \\
\text { Mean (1) }\end{array}$ & $\begin{array}{c}\text { Employees } \\
\text { Mean (2) }\end{array}$ & $\mathbf{t}$ & $\mathbf{p}$ & $\begin{array}{c}\text { St. Dev } \\
\text { Group } 1\end{array}$ & $\begin{array}{l}\text { St. Dev. } \\
\text { Group } 2\end{array}$ \\
\hline $\begin{array}{l}\text { The quality of tourist offer (an } \\
\text { attractive destination place) }\end{array}$ & 8.258 & 6.367 & $4.097 * *$ & 0.0 & 2.497 & 2.885 \\
\hline Price & 6.155 & 6.49 & -0.493 & 0.688 & 3.14 & 1.861 \\
\hline Reputation of organization & 5.918 & 5.265 & $1.663^{*}$ & 0.098 & 2.294 & 2.119 \\
\hline Quality of service in the office & 4.814 & 7.776 & $-7.896 * *$ & 0.0 & 2.261 & 1.874 \\
\hline Quality of service during the trip & 5.732 & 7.429 & $-4.296 * *$ & 0.0 & 2.206 & 2.345 \\
\hline Convenience & 4.969 & 4.408 & 1.575 & 0.118 & 2.069 & 1.957 \\
\hline Safety & 6.567 & 5.796 & $1.713^{*}$ & 0.089 & 2.669 & 2.354 \\
\hline Reliability & 5.567 & 6.388 & $-1.899 *$ & 0.06 & 2.533 & 2.326 \\
\hline $\begin{array}{l}\text { Comparison of the delivered } \\
\text { service with the advertising }\end{array}$ & & & & & & \\
\hline message & 4.711 & 3.531 & $2.478 * *$ & 0.014 & 2.776 & 2.599 \\
\hline Other & 1.485 & 1.306 & 0.604 & 0.547 & 1.809 & 1.402 \\
\hline
\end{tabular}

A similar assessment was conducted among employees of travel agencies. The combined results of this analysis are presented in Table 2. Employees of the surveyed agencies agreed that the most important factor in shaping customer satisfaction is the quality of service in the office (7.776). In the second place they indicated quality of customer service during the trip (7.429). Both factors have been ranked significantly higher by employees than by customers (confirmed by t-test). The fact that travel agencies strongly emphasize importance of customer service means that they understand the value and importance of face-to-face contact with customers. They recognize the strong link between how they react to the client's feelings, attitudes and emotions, with the overall perception of satisfaction in this industry. These results are consistent with the findings of Reisinger and Waryszaka (1994), where they pointed out that verbal skills and the proper conduct of the seller or the person providing the service are crucial for the emergence of satisfaction for the buyer of a tourism product. The high level of satisfaction with customer service can even lead to compensation for negative feelings related to delivery of low quality service by the suppliers (i.e. transportation, accommodation). A customer who believes in a professional, competent and friendly service is more inclined and encouraged to visit a destination suggested by the travel agent. This is a very important element, which should always be remembered, as the activities of travel agencies refer to the provision of satisfaction associated with a highly valuable time for customers - vacation.

Employees' perception of the offer quality, safety and price attribute (means: 6.367; 5.796; 6.49 respectively) have been ranked differently in terms of impact on customer satisfaction. These factors have been indicated by customers as the most important, so it is interesting that we observed large gaps within the results from both groups. The significant differences have been reported in the variable of the "offer quality," where employees did not perceive this as a critical factor affecting customer satisfaction. While it still has been ranked at the above average level, it could confirm that travel agents are more focused on the quality of customer service (in the office: 7.776 and during the trip: 7.429). This is a component that they can control, and they can respond immediately to the customer expectation, whereas the product offering is something that many times they do not have control over. The only aspect of product offering they feel responsible for is presentation of the offer and response to potential questions and concerns. Therefore, they do not see a strong connection between the level of satisfaction and the quality of the offer.

From the other factors ranked highly by customers we did not observe a significant difference in the role of price, but we noticed a statistical difference in perception of safety as an attribute affecting customer satisfaction. It had a lower importance to employees than to customers. This should raise a concern to travel agents that they should be open to discussions about safety concerns and look at this as a potential area of negative impact on the customers' interests in traveling.

Another area that we noticed a significant difference between these two groups of responders was the perception of effects of advertising on customer satisfaction. Employees of travel agencies placed lower importance on the role of "comparison of the delivered service with the advertising message" (mean: 3.531). This is the area 
where travel agents should look at their role in the process of creating expectations. Customer expectation level is very often influenced by messages included in advertising materials. Many times the message and the medium can form unrealistic expectations. Comparison of the advertising message with obtained service during vacation/travel can cause not only lack of satisfaction but even dissatisfaction. Travel agents should not ignore their role in this process because by managing customer expectations they can clarify some of the information that customers obtained from advertising and therefore eliminate potential areas of dissatisfaction.

As obtained results suggest, there are important gaps between the assessments of each attribute that affect customer satisfaction between employees of travel agencies and customers. The fact that customers continue to pay attention to factors such as type of the offer, safety or price, could suggest that operating in this market, travel agents differ in the degree of perceiving satisfaction as a result of fulfillment of these needs. These findings also suggest that these elements could potentially become the basis for the diversification of tourist offers targeted to different groups of customers. A situation in which customers do not see an important connection (indicated in the literature of the subject) between the level of customer service and satisfaction could indicate that based on past experience, customers have not faced situations that could negatively influence their feelings and expectations with this aspect of service.

In order to complete the analysis of determinants that affect customer satisfaction and to confirm the actual level of satisfaction on each of these attributes, we asked customers to rank their level of satisfaction with each distinguished attribute on a scale from 1 to 5, where 1 meant: "not satisfied at all" and 5 meant: "very satisfied." By computing reported values with earlier established means of attribute importance we obtained "adjusted" levels of customer satisfaction. This analysis points out the areas where travel agencies need to actually improve, because it clearly indicates not only how satisfied customers are by each attribute, but also their perception of the importance of these attributes in overall satisfaction. By improving satisfaction in only critical components, travel agencies could quickly increase overall satisfaction with their service, according to practitioner's rule 80/20.

In order to identify the critical areas that investigated companies should improve, we decided to introduce and calculate the "Index of Attributes" (IA) for both groups (customers and employees). We calculated this by multiplying the arithmetic means of attributes evaluation, ranked by degree of importance (from 1 to 10; where: 1 lowest importance and 10 - highest importance) and the averages of the level of satisfaction from each attribute (ranked on a scale from 1 to 5; where: 1 represents very low satisfaction, and 5 is the highest), and then treated as individually assigned weights of importance. In the case of customers we asked them about their actual level of customer satisfaction based on their experience with the travel agency. On the other hand we asked employees about their perception of how customers are evaluating satisfaction with services obtained by the travel agency they represent. Given the possibility of obtaining a maximum of 275 points, we obtained the results presented in Table 3. The sum of individual indexes of each attribute $(\Sigma I A)$ represented the overall customer satisfaction from services delivered by the travel agency.

The results indicate critical areas that managers in travel agencies should focus their attention on in order to better respond to customers' expectations. In this study customers indicated a higher level of satisfaction from the services in this sector (79.66\%) compared with employees perception of customer satisfaction $(75.52 \%)$. This could suggest that employees realistically evaluate their work. This analysis indicates that managers of travel agencies should focus attention on attributes that employees ranked lower than customers, because these are the areas that are underestimated by employees. In this case these are: "the quality of the offer," "safety," "convenience," "comparison of the delivered service with the advertising message" and "reputation of organization." These findings are consistent with previous conclusions that employees of travel agencies did not pay enough attention to these areas and do not clearly understand their importance to customers. Interestingly, calculating the Index of Attributes of the "convenience" factor we noticed higher importance of this factor to customers, whereas when asked directly about its importance, customers evaluated it at an average level (mean: 4.969), which also was not significantly different from the employees' opinions. This means that customers place more weight on "convenience" in the overall satisfaction, but they are not fully aware of its importance to them. 
Table 3. Index of Attributes (IA) for Each Attribute Affecting Customer Satisfaction

\begin{tabular}{|c|c|c|c|c|c|c|c|}
\hline \multirow[b]{3}{*}{ Attribute } & \multicolumn{3}{|c|}{ Customers } & \multicolumn{3}{|c|}{ Employees } & \multirow{3}{*}{$\begin{array}{c}\text { Difference } \\
\text { IA }_{1}-\mathbf{I A}_{2} \\
\%\end{array}$} \\
\hline & \multicolumn{2}{|c|}{$\left(\right.$ Mean $\left.\mathrm{n}_{1}=527\right)$} & \multirow{2}{*}{\begin{tabular}{|c|}
$I A_{1}$ \\
$\%$
\end{tabular}} & \multicolumn{2}{|c|}{$\left(\right.$ Mean $\left.\mathrm{n}_{2}=48\right)$} & \multirow{2}{*}{$\begin{array}{c}\mathrm{IA}_{2} \\
\% \\
\end{array}$} & \\
\hline & $\begin{array}{l}\text { Scale } \\
1-10\end{array}$ & \begin{tabular}{|c|} 
Scale \\
$1-5$ \\
\end{tabular} & & \begin{tabular}{|c|} 
Scale \\
$1-10$ \\
\end{tabular} & $\begin{array}{c}\text { Scale } \\
1-5\end{array}$ & & \\
\hline The quality of tourism offer (an attractive destination place) & 8.258 & 4.2 & $12.61 \%$ & 6.367 & 3.98 & $9.21 \%$ & $3.40 \%$ \\
\hline Price & 6.155 & 4.1 & $9.18 \%$ & 6.49 & 4.17 & $9.84 \%$ & $-0.66 \%$ \\
\hline Reputation of organization & 5.918 & 4.1 & $8.82 \%$ & 5.265 & 3.94 & $7.54 \%$ & $1.28 \%$ \\
\hline Quality of service in the office & 4.814 & 3.9 & $6.83 \%$ & 7.776 & 3.77 & $10.66 \%$ & $-3.83 \%$ \\
\hline Quality of service during the trip & 5.732 & 4.1 & $8.55 \%$ & 7.429 & 4.71 & $12.72 \%$ & $-4.18 \%$ \\
\hline Convenience & 4.969 & 3.9 & $7.05 \%$ & 4.408 & 3.06 & $4.90 \%$ & $2.14 \%$ \\
\hline Safety & 6.567 & 4.5 & $10.75 \%$ & 5.796 & 3.81 & $\mathbf{8 . 0 3 \%}$ & $2.72 \%$ \\
\hline Reliability & 5.567 & 4.2 & $8.50 \%$ & 6.388 & 3.56 & $8.27 \%$ & $\mathbf{0 . 2 3 \%}$ \\
\hline Comparison of the delivered service with the advertising message & 4.711 & 3.9 & $6.68 \%$ & 3.531 & 2.98 & $3.83 \%$ & $2.85 \%$ \\
\hline Other & 1.485 & 1.3 & $0.70 \%$ & 1.306 & 1.06 & $0.50 \%$ & $0.20 \%$ \\
\hline $\begin{array}{l}\text { Total }(\Sigma I A) \\
\text { (Overall Customer Satisfaction) }\end{array}$ & & & $79.66 \%$ & & & $75.52 \%$ & $4.15 \%$ \\
\hline
\end{tabular}

\section{Customer Satisfaction Knowledge Assessment}

Analysis of obtained data allowed us to specify the linkages and benefits of monitoring customer satisfaction in this industry. We made an attempt to analyze the level of satisfaction and business performance of investigated organizations. Due to some difficulties for managers and employees in defining the issue of satisfaction (and a certain abstraction of the concept), the collected responses indicated a lack of understanding of the direct relationship between the level of customer satisfaction and business performance in analyzed travel agencies. However, we were able to identify this relationship based on economic and non-economic effects that resulted from delivered high levels of satisfaction. The actual effects and tendencies from a certain level of satisfaction were observed by analyzing customers, employees and managers responses. A synthetic approach to the satisfaction surveys and results of the interviews are available from the author. These results present a summary of case studies for organizations (coded with symbols from I to VIII) from which we were able to collect a complete set of data.

In order to determine the managers' understanding of the investigated topic we asked managers if they are conducting measurements of customer satisfaction and what type of methods and techniques they apply. We verified their declaration with the results gathered from employees' surveys. Follow up questions about methods used to collect this information helped us to initially verify their statements. These questions also helped us recognize managers' perception of methods that can be used to track levels of customer satisfaction.

Detailed analysis of eight organizations revealed that the companies generally do not apply the measurements of satisfaction. Only the entities marked as III, IV and V conducted customer satisfaction measurements. The measurements took place mostly within the periodic market studies, most often in the form of conducting surveys and analysis of complaints. Travel agencies marked III and IV used a more sophisticated approach of implementing a mystery shopping technique and analysis of reports of first contact employees' (V). Specifically designed as a method for tracking customer satisfaction levels, mystery shopping was used by the organizations that operated as a franchise. Therefore, we could observe the impact of training and knowledge transfer from the parent company down to the operational level. It is worth mentioning that among three companies that have conducted measurements of customer satisfaction, only one travel agency (V) reported that they are seeing clear benefits of these measurements and a direct relationship with business performance.

This is a good indicator that managers are seeing the possibility of using existing methods to assess customer satisfaction. However, it can suggest that managers are not prepared to utilize specially designed methods to track this trend. Moreover, many managers still do not believe in the benefits of conducting this type of analysis. The remaining organizations (I, II, VI, VII and VIII) declared that they also conduct market research, using analyses of warranty claims and complaints and monitoring sales levels. However managers didn't connect these activities with customer satisfaction measurements. Based on these responses we could conclude that the level of understanding and managers' knowledge of the problems of customer satisfaction is relatively low. We confirmed 
our findings through analysis of the employees' survey. We asked questions about the reasons for not measuring customer satisfaction. Half of the surveyed employees (50\%) of travel agencies identified as a main problem insufficient knowledge of this issue. Employees did not blame managers for this state (only $2 \%$ indicated this as a problem), which is a positive message; however it also illustrates the lack of interest in tracking customer satisfaction. The reason for this situation could be explained by the other factor - too much focus on day-to-day operations (100\% answers) as well as not enough time for proper customer relationship management (29\%). Lack of financial resources has been identified as a barrier by only $4 \%$ of respondents. This situation indicates that in the eyes of employees, management is open to innovative approaches, and it would be possible in the future to secure financial support for developing tools for tracking customer satisfaction. Conditionally, there would be enough motivation to pursue this in the future.

We asked employees of these travel agencies about the importance of measuring satisfaction and its implication for future development of the organization. In all cases respondents indicated high importance. Some employees even stated that customer satisfaction "can play a key role" in shaping future directions. However, by comparing the stated opinions with managers' actions and methods implemented by organizations, we observe that so far these intentions are remaining in the declared state and are not implemented in life. This is confirmed by the overwhelming responses that high accumulations of daily tasks and responsibilities, as well as lack of knowledge about the concept of customer satisfaction, have been seen as the main barriers that prevent developments in this area. Consequently, lack of time to perform extra assignments has adversely affected elimination of the other obstacle - lack of knowledge. It means that in investigated organizations these problems are ignored and there are no signs of actions and activities aimed at improving this situation. We also could not see managers' effort to solve this problem, because they are not interested in obtaining information about this situation.

We made an attempt to identify the opinions about possible benefits of the measurements and the effects of a high level of satisfaction. Collected answers clearly indicate that employees are considering a possible relationship between customer satisfaction and the results of business activity, in both financial and non-financial outcomes. The responses of the staff of all (except one - III) agencies indicated that the most important direct benefit is the improvement of a tourism offer that better responds to customer expectations. Three enterprises (II, III, VI) indicated that by improving customer satisfaction they could improve operations and management processes across the business organization. Obtained results imply the importance of customer satisfaction measurements as a source of information about areas that should be improved (III, VII, VIII), as well as a credible source of market information $(\mathrm{V}, \mathrm{VI})$. The other effects of providing customer satisfaction could be the ability to build a positive corporate image and increase sales levels. Some organizations (II, III, IV, VIII) pointed out the impact of customer satisfaction on the increase in customer loyalty, and reductions of complaint behavior (I, II, III, VIII). Enterprise (IV) indicated that this could potentially result in a reduction of operating costs.

Although we conducted independent measurements of customer satisfaction, we asked managers of investigated organizations about their perception of how satisfied their customers are. This allowed us to determine the managers' knowledge of the issue of customer satisfaction. We asked a question about identification of factors influencing the reduction in perceived levels of satisfaction. The similar responses to these questions among all travel agencies suggest that managers in these companies apply soft criteria to self-evaluation (all reported high levels of customer satisfaction) and do not admit to having a significant number of dissatisfied customers. Among factors reducing the level of satisfaction they pointed out service guarantees (during actual travel or vacation), activities performed in a timely manner (all except IV), unmet customer expectations (all except I and VII), and improper handling of complaints and reported problems (II, III and VII).

Based on collected data from customers we were able to calculate the level of customer satisfaction for each analyzed company. Only three companies achieved a level of satisfaction that could be described as high, ranging from 79 to $82 \%$ (I, V, VIII). The remaining travel agencies have been evaluated at levels from $67 \%$ to $74 \%$. Among travel agencies that scored highest, more than $50 \%$ of customers were very satisfied with services. Two of these travel agencies (I and VIII) had only $1 \%$ of customers slightly dissatisfied and no customer that expressed a stronger negative opinion than this. Other companies had customers that have been very or highly dissatisfied - up to $5 \%$. Some companies could probably score higher on the overall scale of customer satisfaction; however customers had problems evaluating their service. For example: organization IV had a significant portion of customers who 
were unable to provide evaluations (up to $43 \%$ ), but they still have satisfied customers (combined - $38 \%$, overall satisfaction - 74\%). This could suggest that customers were probably satisfied with one attribute of the travel agency's services but were greatly dissatisfied with another one consequently creating mixed emotions and making it difficult to provide a straightforward evaluation. This type of situation highlights the shortcomings of implementing only one method of tracking customer satisfaction. In order to further investigate the causes of potential problems with customer satisfaction levels, we can study customer behavior by using the critical incidents technique. This approach makes it possible to identify critical areas of business operations because it focuses on the most memorable events (both positive and negative) associated with obtained services. In most cases the negative situations that made the greatest impressions were connected primarily with the experience of transportation (bus, air, problems with connections). This is problematic for travel agencies because these organizations do not provide actual transportation but only make arrangements with actual service providers; therefore they do not have direct control over the quality of transportation. However, travel agencies can identify which subsidiary does not provide quality service and discontinue their service. This action could lead to improvement of the image of the travel agency in the future. It should be remembered that customers purchasing a tourism product perceive this completely as a good purchased from a travel agent (tourism package) and do not see this as a sum of individual services from "sub-contractors." For that reason, a faulty or low quality component of the "tourism package" delivered by a subsidiary can cause deterioration of the level of customer satisfaction for a travel agency and reflect on the overall corporate image.

Positive situations that have been memorized occurred mostly during the vacation or travel and were associated with the customer service delivered by tour guides, residents, hotel staff, etc., as well as the attractiveness of the tourist destination itself. Strengthening these types of situations and events could be a relatively easy way to build a strong, positive message to customers, and therefore improve customer satisfaction.

\section{Effects of Customer Satisfaction}

Achievement of high levels of customer satisfaction is a goal that should result in modification of customer behavior in terms of increasing the propensity of repeat purchases, that: (1) improve overall sales level (Harting, 1998; Bolton, et al. 2000); (2) increase in customer loyalty (Fornell, 1992; Bolton, 1998; Morgan, et al. 2000); and (3) positively affect recommendations to others (Fornell, 1992; Anderson and Sullivan, 1993; Zairi, 2000; Anderson, et al. 2004; Wangnheim and Bayon, 2004). Based on collected information from customers we observed a close relationship between their level of satisfaction and their behavior.

\section{Customer Recommendations}

Customers of companies that provide services at above average levels are more prone to express positive opinions about these businesses than to criticize or remain indifferent. For the travel agency (I) with the highest rate of customer satisfaction - $82 \%$, we observed the highest propensity to transmit positive feedback (word-of-mouth) mean value of 5.99 (on the scale from 1 to 7, where 1 means "not at all," and 7 - "definitely") and one of the lowest propensities to convey negative comments -2.13 points. For the second company (V) with the highest level of customer satisfaction (82\%) the corresponding values were as follows: 5.32 - positive feedback and 2.97 - negative feedback. Similar tendencies have been observed for the travel agency (VIII) that also reported high levels of customer satisfaction (79\%) positive word-of-mouth effect - 5.38 points and 2.87 negative word-of-mouth effect. Confirmation of this tendency is the situation observed in the travel agency (III) with the lowest value of the analyzed indicator of customer satisfaction - 67\%, where we observed a much stronger tendency to express negative opinions (mean - 3.61; highest among analyzed organizations) and lack of motivation to express positive messages (average 4.45; the lowest reported). The consequence of the existence of a positive word-of-mouth effect is the potential to acquire new customers by positive recommendation from satisfied customers. Customers' recommendations to friends, family members and other people they interact with, become free and credible advertising of this business, which could greatly benefit the company.

\section{Customer Loyalty in Travel Agencies}


A strong correlation between satisfaction and customer loyalty, as identified in the literature (McDougall, Levesque 2000), has found confirmation in this study. Indeed, customers that have been highly satisfied with a travel agency expressed a greater tendency to make declarations of repeat purchases or long-term commitment. We attribute this to two main reasons. First, the satisfied customers want to minimize the risk of failure in the future, because the vacation time cannot be restored if there is a problem with quality of obtained service. Therefore, they would return to the travel agency, which provided great quality and assurance of service. Customers are aware that they can still choose a variety of services (travel packages, different destinations, etc.) by using the services of one chosen travel agency. Second, returning to the known company that in the past accurately recognized and satisfied their needs can reduce the risk of a wrong choice, because tourists many times are not fully aware of their needs or have difficulty expressing them. As described by the study of tourism services (Kobylanski and Kaliszewicz, 2003) we should consider loyalty in reference only to the travel agency itself, and not the tourism product. Only occasionally would tourists who use specialized intermediaries like travel agencies (even if they are very satisfied) be shopping for the same travel package. Repeated contact with the company will most likely be motivated by a need to buy a different tourism product. Thus for customers, being highly satisfied with the first offer they used becomes a kind of "guarantee" of a high level of service in the future.

For the first travel agency ( $\mathrm{I} ; I A=82 \%$ ), the customers' declaration of willingness to conduct repeat purchases at a seven-point scale (1 means "low" and 7 represents "high") was 5.57, and the value most often indicated (model) was 7. An almost identical relationship has been observed for the enterprise V $(I A=82 \%)$ where the average value was a little bit higher - 5.76, and reported value of the model was also 7 . A less visible tendency has been observed in travel agency VIII $(I A=79 \%)$ - average 5.14, and value of model -5 . These results indicate a higher propensity to become a loyal customer for travel agencies that provide a higher level of customer satisfaction. We observed that the lower the level of satisfaction, the more customers are looking for other service providers. Among the remaining organizations (II, III, IV, VI, and VII) the declarations of loyalty behavior range from 4.5 to 4.95 (model between 4 and 6) that characterize situations of low motivation to articulate a clear declaration. We have confirmed obtained results by analyzing the structure of customers, in terms of frequency of contact with the investigated travel agencies. Among customers of travel agencies I, V and VIII we observed a significant portion of loyal customers $(32.3 \%, 77.8 \%, 21.8 \%$ respectively), while for travel agencies with lower levels of satisfaction the group of loyal customers varied from $12.5 \%$ to $23.3 \%$. We found our results conclusive with previous studies that indicated the customer's satisfaction with the performance of the supplier; trust in this supplier and the perceived commitment to the supplier are the key variables underlying relationship quality and thus loyalty (Baker et al., 1999; Garbarino and Johnson, 1999; Smith, 1998).

\section{CONCLUSIONS}

Conducting measurements of customer satisfaction in Polish companies is still not widely recognized as a valuable tool to improve business performance. This should be considered as an important practice in the travel agencies sector where interactions with customers are the main component in the process of satisfying customer needs. Based on the literature discussion and our findings, we were able to verify the stated hypothesis and provide some conclusions. As expected, we found that only $26.7 \%$ of investigated travel agencies performed measurements of the level of customer satisfaction. Identified methods most often were implemented as a part of standard market research, and only in two cases did organizations utilize specially-designed methods of customer satisfaction evaluation (mystery shopping). Other companies, despite indications of conducting various marketing research methods (analysis of complaints, monitoring sales levels, customer surveys, etc.) were not making any connection between collected information and the level of customer satisfaction. The investigation of potential reasons for this state has lead us to positive verification of the Hypothesis I. Observed difficulties in defining the concept of customer satisfaction and the minimal use of explicit methods for measuring customer satisfaction (caused by low business manager awareness about of this issue) have been the main barriers to implementation of measurements of satisfaction. We did not observe any efforts and activities aimed at improving this situation. Managers' lack of commitment and awareness of customer satisfaction have been confirmed to be the difference in the perception of customer satisfaction and the actual level that has been calculated during this study. Moreover, we found that the concept of customer satisfaction is unknown to most employees of investigated travel agencies. A high volume of daily tasks and responsibilities is the main reason indicated for the situation. This can suggest that there is the 
potential to search for information on this subject, but it is inhibited by the lack of time.

A comprehensive assessment of the attributes of the services provided by the travel agencies revealed that the main determinants of satisfaction in this market are price and quality of the offer. Both customers and travel agents assessed attributes of price similarly. However, there were significant differences between the two groups in perception of the impact on satisfaction in the following attributes: "quality of the offer," "quality of service in the office," "quality of customer service during the trip," "safety" and "advertising" effect. By identification and improvements in only critical-to-customer components, travel agencies could quickly leverage overall satisfaction, and be more efficient in responding to customer needs (positive verification of Hypothesis II).

Conducted studies allowed us to positively verify Hypothesis III. Using a mostly qualitative approach, we recognized the positive impact of customer satisfaction on non-financial results, thus showing potential for improving business performance.

First, a high level of customer satisfaction has an impact on the propensity to provide greater positive and lower negative opinions about the company. Secondly, we observed the influence of high satisfaction on customer loyalty. We also noticed that employees themselves could see the potential benefits of conducting measurements of customer satisfaction, which could result in improvement of the tourist product offering, identification of problematic areas and improvement of the overall business performance.

\section{IMPLICATIONS FOR FUTURE RESEARCH}

We believe that our findings could greatly benefit companies in the travel agencies sector. Acknowledgment of the importance and positive effects of customer satisfaction have critical importance in the service sector which is inextricably linked to a client, because indeed customers are taking an important part in the service and personal experiences are very important. Thus, both parties - travel agency and customer - influence the final outcome of this relationship.

The area of future research should primarily address the limitation of this study. An important limitation of this research was the scope of the sample, which was concentrated in one particular country. Therefore there is a need to replicate this study with samples from other countries, especially to provide cross-cultural perspective.

Because of changes in technology development and the popularity of online travel services, it would be interesting to investigate the differences between satisfaction from traditional travel agencies and online travel agents. We could then determine if the same set of attributes equally influences overall satisfaction with real and on-line environments.

\section{AUTHOR INFORMATION}

Professor Andrzej Kobylanski, Ph.D., is assistant professor of marketing at Penn State Greater Allegheny, USA. E-mail: auk20@psu.edu.

\section{REFERENCES}

1. Anderson, E.W. \& Sullivan, M.W. (1993). "The antecedents and consequences of customer satisfaction for firms.” Marketing Science, 12(2), 125-143.

2. Anderson, E.W. (1996). "Customer Satisfaction and Price Tolerance," Marketing Letters, 7 (3), 19-30.

3. Anderson, E.W., Fornell, C. \& Mazvacheryl, S.K. (2004), "Customer Satisfaction and Shareholder Value." Journal of Marketing, 68 (Oct.), 172-185.

4. $\quad$ Baker, T.L., Simpson, P.M. \& Siguaw, J.A. (1999). "The Impact of Suppliers Perceptions of Reseller Market Orientation on Key Relationship Constructs." Journal of the Academy of Marketing Science, 27(1), $50-57$.

5. Barlow J. \& Moller C. (2001). "Reklamacja czyli prezent. Strategia korzystania z informacji od klienta." 
(trans. A complaint is a gift. The strategy to use information from the customer), Science Publishing House, PWN, Warsaw, Poland.

6. Bolton, R.N. (1998). "A Dynamic Model of the Duration of the Customer's Relationship with a Continuous Service Provider: The Role of Satisfaction.” Marketing Science, 17 (1), 45-65.

7. Bolton R.N., Kannan, P.K. \& Bramlett, M.D. (2000). "Implications of Loyalty Program Membership and Service Experiences for Customer Retention and Value." Journal of the Academy of Marketing Science, 28 (1), 95-108.

8. $\quad$ Fornell, C. (1992). “A National Customer Satisfaction Barometer: The Swedish Experience.” Journal of Marketing, 56(1), 6-22.

9. Fornell, C. (1995). "The Quality of Economic Output: Empirical Generalizations About Its Distribution and Relationship to Market Share.” Marketing Science, 14 (3), 203-211.

10. Fornell, C., Johnson, M.D., Anderson, E.W., Cha, J. \& Everitt Bryant, B. (1996), "The American Customer Satisfaction Index: Nature, Purpose, and Findings," Journal of Marketing, 60 (October), 7-18.

11. Fornell, C., Mithas, S., Morgeson III, V.F. \& Krishnan, M.S. (2006). "Customer Satisfaction and Stock Prices: High Returns, Low Risk.” Journal of Marketing, 70 (January), 3-14.

12. Garbarino, E. \& Johnson, M. K. (1999). "The Different Roles of Satisfaction, Trust and Commitment in Customer Relationships.” Journal of Marketing, 63 (April), 70-87.

13. Gounaris, S. \& Stathakopoulos, V. (2001). "Behavioral responses to customer satisfaction: an empirical study." European Journal of Marketing, 35(5/6), 687-670.

14. Harting D. (1998). "Zadowolenie klientów, lecz nie nadmiernym kosztem." (trans. Customer Satisfaction but not an excessive cost) Zarzadzanie na Świecie, 4, 46-47.

15. Henning-Thurau, T., Gwinner, K.P. \& Gremler, D.D. (2002). “A Integration of Relational Benefits and Relationship Quality." Journal of Service Research, 4(3), 230-247.

16. Kobylanski A., \& Kaliszewicz D. (2003). "Satysfakcja i lojalność klientów jako elementy konkurencyjne przedsiębiorstw zajmujących się obsługą ruchu turystycznego," (trans. Customer satisfaction and customer loyalty as elements of competitive advantage in travel agencies). Biuletyn Naukowy, 20 (1), 179-187.

17. Lawson G., \& Glowa T. (2000). "Satisfaction measurement: Is it worth it?" Quirk's Marketing Research Review, www.quirks.com, No 0618.

18. McDougall G.H.G. \& Levesque T. (2000). "Customer satisfaction with services: putting perceived value into equation.” Journal of Services Marketing, 14(5), 392-410.

19. Mithas, S. Jones, J.L. \& and Mitchell, W. (2004). "Determinants of Governance Choice in Business-toBusiness Electronic Markets: An Empirical Analysis." Ross School of Business, University of Michigan.

20. Moliner, M.A., Sanchez, J., Rodriguez, R.M. \& Callarisa, L. (2007). "Relationship quality with a travel agency: The influence of the postpurchase perceived value of a tourism package." Tourism and Hospitality Research, 7(3/4), 194-211.

21. Morgan R.E., Strati M., McGuinness T. \& Dennis C. (2000). "Determinants of customer brand switching behavior." AM 2000 Conference Proceedings of Academy of Marketing Annual Conference, Derby.

22. Naumann, E. \& Hoisington, S.E. (2001). Customer Centered Six Sigma: Linking Customers, Process Improvement, and Financial Results. Milwaukee: ASQ Quality Press.

23. Olliver R.L. (1995). “Attribute need fulfillment in product usage satisfaction." Psychology and Marketing, 12(1), 1-17.

24. Oliver, R. L. (1980). A cognitive model of the antecedents and consequences of satisfaction decisions.” Journal of Marketing Research, 17, 460-469.

25. Oliver, R.L. (1997). "Satisfaction: A behavioral perspective on the customer", McGraw-Hill, New York.

26. $\quad$ Oliver, R. (1999). "Whence Consumer Loyalty?' Journal of Marketing, 63 (Special issue), 33-45.

27. P-EN-ISO 9000: (2000), September, (2001), p.27.

28. Parasuraman, A., Zeithaml, V.A. \& Berry, L.L. (1985). "Conceptual Model of Services Quality and Its Implications for Future Research.” Journal of Marketing, 49 (Fall), 41-50.

29. Pasquier, M. \& Fastnacht, R. (2001). "Badania satysfakcji klientów." (trans. Customer satisfaction measurements) Zarzadzanie na Świecie, 6, 45-47.

30. Radhakrishna R. (2002). "Measuring and Benchmarking Customer Satisfaction: Implications for Organizational and Stakeholder Accountability." Journal of Extension, 40 (1).

31. Robertson, T. S. \& Gatignon, H. (1986). "Competitive effects on technology diffusion.” Journal of 
Marketing, 50(July), 233-255.

32. Rust, R.T. \& Zahorik, A.J. (1993). "Customer Satisfaction, Customer Retention, and Market Share," Journal of Retailing, 69 (Summer), 145-156.

33. Rust, R.T., Moorman, C. \& Dickson, P.R. (2002). "Getting Return on Quality: Revenue Expansion, Cost Reduction, or Both?” Journal of Marketing, 66 (October), 7-24.

34. Schneider, W. (2000). "Kunder - zufriedenheit. Strategie. Messung. Management“, Verlag Moderne Industrie, Landsberg

35. Shen X.X., Tan K.C., \& Xie M. (2000). "An integrated approach to innovative product development using Kano's model and QFD.” European Journal of Innovation Management, 3(2), 91-99.

36. Smith, J. B. (1998). "Buyer-Seller Relationships: Similarity, relationship management, and quality." Psychology \& Marketing, 15(1), 3-21.

37. Tan K.C. \& Pawitra T.A. (2001). "Integrating SERVQUAL and Kano's model into QFD for service excellence development." Managing Service Quality, 11(6), 418-430.

38. Wangnheim, F. \& Bayon, T. (2004) Satisfaction, loyalty and word of mouth within the customer base of a utility provider: differences between stayers, switchers and referral switchers, Journal of Consumer Behavior, 3, 211-220.

39. Warnock P. (1992). Surveying Client Satisfaction. Journal of Extension, Spring.

40. Woodruff, R.B. \& Gardial, S.F. (1996). "Know Your Customer. New Approaches to Understanding Customer Value and Satisfaction." Blackwell Publishers Inc.

41. Yu, S-H. (2007). An Empirical Investigation on the Economic Consequences of Customer Satisfaction." Total Quality Management, 18(5), 555-569.

42. Zairi, M. (2000). "Managing customer satisfaction: a best practice perspective", The TQM Magazine, 12(6), 389-394.

43. Zeithaml, V.A. \& Bitner, M.J. (2000) Service Marketing: Integrating Customer Focus Across the Firm, Boston, MA: Irwin McGraw-Hill. 